\title{
KOMMENTTI RISTO HEISKALALLE
}

Risto Heiskala on mielenkiintoisessa arvostelussaan (Tiede \& Edistys 3/1984) artikkelikokoelmastani Yhteiskuntateoria ja emansipaatio (Tutkijaliiton julkaisusarja no. 26, Helsinki 1984) kommentoinut erityisesti kokoelmani viimeistä ja aikaisemmin julkaisematonta artikkelia "Rikkaus ja vapaa aika emansipaatiotavoitteena". Heiskala ei ainoastaan kritisoi omaa tulkintaani Marxin välttămăttömyyden ja vapauden valtakunnista, vaan esittää myös oman tulkintansa ja vieläpä oman ehdotuksensa "kommunismin ensimmäisen vaiheen" organisaatioprinsiipiksi. Artikkelissani, jota Heiskalakin laajasti referoi, olen esittänyt kaksi erilaista mahdollisuutta tulkita Marxin kommunismikäsitystä ja siihen liittyviä välttämättömyyden ja vapauden valtakuntia. Ensimmäinen näistä tulkinnoista, jota kutsun aristoteliseksi, keskittyy erilaisiin toiminnan määreisiin vapauden ja välttämättömyyden valtakunnissa ja Marxin käsitykseen vapaasta itsensä toteuttamisesta vapauden valtakunnan toiminnan määreenä. Toinen, kantilaiseksi luonnehtimani, keskittyy autonomian ja heteronomian käsitteisiin ja ihminen-luonto suhteeseen: vapauden valtakunnassa toimintaa säätelevät tällöin vain empiirisistä ehdoista riippumattomat moraaliset lait, joiden lähteenä on vain yksilön autonomia ja vapaa tahto. Olen lisäksi pyrkinyt tarkastelemaan näihin molempiin käsityksiin liittyviå ongelmia, jotka koskevat toisaalta sitä, että itsensätoteuttaminen on välttämättä lajiolemuksen itsensätoteuttamista - kanta, jota Marx itse on kritisoinut ja "Saksalaisessa ideologiassa - ja toisaalta sitä, että Marxin kommunismi on kaiken yhteiskunnallisuuden tuolla puolen, eikä siihen siten sisälly mitään aidon rikkauden tai hyvän elämän yhteiskunnallisia määreitä.

Kuten Heiskala itsekin myön- tää, Marxilta löytyy sellaisia luonnehdintoja, jotka antavat tukea ensimmäiselle tulkinnalle: Marx sanoo eksplisiittisesti, että itsensätoteuttaminen kuuluu vapauden valtakunnan piiriin. Toinen tulkinta on ongelmallisempi: Lohmannin, "johon tulkinnassani nojaan", idea on lähinnä yritys pelastaa Marxin emansipaatiotavoite ja kehitellä eräänlaiselta kantilais-habermasilaiselta pohjalta järkeviä normatiivisia kriteereitä aidolle yhteiskunnalliselle rikkaudelle.

Heiskalan kommentin varsinainen anti on oman ratkaisun esittäminen sille, mitä Marx välttämättömyyden ja vapauden valtakunnilla tarkoittaa ja miten niiden välinen suhde voitaisiin kommunismin ensimmäisesä vaiheessa järkevästi tulkita. Heiskalan tulkinta nojaa kahteen Marxin luonnehditaan. Grundrissessd Marx puhuu "disposable timesta", joka kapitalismissa esiintyy lisätyöaikana, mutta joka kapitalismin kumouduttua muuttuisi aidoksi vapaaksi ajaksi. Kehittäessään periaatteessa rajattomasti työn tuotantovoimaa ja lisätyöaikaa kapitalismi luo siten kommunismin aidon ja laajan vapaan ajan mahdollisuuden. Kun vapauden valtakunta tulkitaan yhteiskunnallisesti välttämättömän työajan ulkopuolelle jääväksi ajaksi, on Heiskalan mukaan mahdollista erottaa toisistaan käsitteellisesti vapaa aika ja aito itsensätoteuttaminen. Vapaan ajan käsite viittaa tällöin kokonaisyhteiskunnalliselle tasolle, ja siten itsensätoteuttamiseen liittyvät ongelmat voidaan sivuuttaa. Vapaan ajan alue olisi siten sama kuin vapauden valtakunta, joka jää yhteiskunnallisesti välttämättömän työajan ulkopuolelle. Toinen Marxin Heiskalan tulkintaa tukeva kohta löytyy Pääomasta, jossa Marx toteaa, että vapauden valtakunta"... on varsinaisen aineellisen tuotannon alueen tuolla puolen". Heiskalan mukaan Marx ei siis väitä sen olevan kai- ken aineellisen tuotannon ulkopuolella, vaan ainoastaan varsinaisen aineellisen tuotannon ulkopuolella. Jos Marxia tulkitaan näin "vălttämättömyyden valtakunnan sfääri määräytyisi pelkästään yhteiskunnallisten ominaisuuksien perusteella" eikä vapauden valtakunnalle tarvitse eikä voida antaa mitään "positiivisia määreitä". Näin sivuutetaan ne ongelmat, joita oman tulkintani mukaan Marxin kommunismikäsitykseen liittyy.

Heiskala on näin löytänyt Marxin vapauden ja välttämättömyyden valtakuntien luonnehdintoihin sisältyvän "järkevän ytimen". Sen yli menevät Marxin luonnehdinnat, joita Heiskalakin Marxilta myöntăă löytyvän. "vain osoittavat, että aiheen käsittely jäi Marxilta kesken". Kun Heiskala vielä liittăä tulkintaansa Agnes Hellerilta peräisin olevan ajatuksen demokraattisesta tarvekeskustelusta, jonka tehtävänä on ratkaista, kuinka suuri yhteiskunnallisesti välttämätön työaika kulloinkin on, sekä kuka määrää ja miten välttämăttömän työn ja tuotannon määrän ja sisällön. Heiskala on esittänyt oman mallinsa kommunismin ensimmäisen vaiheen organisaatiopriisiipiksi. Tämän ehdotuksen etuna on Heiskalan mielestä kaiken lisäksi se, että se yhdistää tarvekeskustelun avulla vapauden ja välttämättömyyden valtakunnat ja jättää toisaalta kuitenkin vapauden valtakunnan "hyvän elämän" erilaisten inhimillisten yhteisöjen vapaasti päätettäväksi.

Hellerin käsitykseen demokraattisesta tarvekeskustelusta liittyy eräită ongelmia, joita Heiskala ei käsittele. Mihin demokraattisen tarvekeskustelun mahdollisuus perustuu? Vaikka sillä onkin eittămättä yhteys Habermasin herruudesta vapaaseen kommunikaation omaan rationaliteettiin, sen enempää Heller kuin Heiskalakaan ei sitä sen paremmin perustele. Ongelmallista on myös Heiskalan tapa käsittää 
vapauden ja välttämättömyyden valtakunnat Gorzin tapaan yhteiskunnallisiksi sfääreiksi, eräänlaisiksi yhteiskunnan osaalueiksi, jotka sitten voivat olla yhteydessä toisiinsa jonkin välityksen kautta. Tällaista ajatusta ei Marxilta ainakaan suoraan löydy.-- Ongelmallisinta kuitenkin oman tulkintani kritiikin kannalta on se, että Heiskala ei lainkaan suhteuta tulkintaansa Marxin kapitalismikritiikin peruslähtökohtiin. Heiskalan tulkinta voi siten olla "järkevä", muttei kuitenkaan välttämättä Marxilta löytyvä. Kritiikkini on eksegeettistä, eikä sellaisena voi "kumota" Heiskalan ohjelmaa, mutta Heiskalan esittämän oman tulkintani kritiikin kannalta se on kuitenkin olennaista. Artikkelini "Rikkaus ja vapaa aika emansipaatiotavoitteena" ei nimittäin yritä olla muuta kuin problematisoiva Marx-tulkinta.

Tässä suhteessa on olennaista Marxin luonnehdinnoissa esiintyvän itsensätoteuttamisen tai itse itsensä päämääränä olemisen liittyminen eräisiin Marxin kapitalismikritiikin peruslähtökohtiin ja -käsitteisiin. Tällöin voidaan käsittääkseni osoittaa, että Marxin luonnehdinnat vapauden valtakunnan toimintaperiaatteesta eivät ole vain Marxin keskenjääneen tarkastelun satunnaisia piirteitä, joilla Marx olisi pyrkinyt antamaan edes jotain sisältöä kommunismilleen, vaan liittyvät kiinteästi hänen työn käsitteeseensä. Ja tätä olen pyrkinyt artikkelissani tarkastelemaan, vaikka ilmeisesti tarkasteluni onkin jäänyt liian hämäräksi, kuten Heiskala toteaa.

Olen väittänyt että Marxin kommunismikäsityksiin liittyy ainakin kaksi ongelmaa. Ensinnäkin puhuessaan kommunismista, joka toteuttaa periaatteen "kullekin tarpeidensa mukaan". Marx joutuu ajattelemaan näitä tarpeita lajiolemuksen tarpeina ja kommunismia aidon lajiolemuksen toteutumana. Tätä tulkintaa tukee se, että Marx ei esitä mitään yhteiskunnallista välitystä, joka toteuttaisi rikkaan yksilöllisyyden ja siihen liittyvät periaatteessa rajattomat tarpeet. Toisaalta väitän, että kun Marx puhuu itsensätoteuttamisesta tai itse itsensä päämääränä olemisesta tämä liittyy Marxin työn esineellistymiskäsitykseen. Marx näyttää ilmeisesti ajattelevan elävän työn esineellistyvän tuotteisiinsa ja viime kädessä kaikkien yhteiskunnallisten objektivaatioiden olevan työn esineellistymiä. Tällöin esimerkiksi yhteiskunnalliset tuotantovoimat - jotka kapitalismissa esiintyvät vieraantuneessa muodossa pääoman tuotantovoimina - ovat viime kädessä aina palautettavissa työläisen ja työn tuotantovoimiksi. Marx ei siten voi lainkaan ajatella ei-esineellistyneitä ja ei-vieraantuneita yhteiskunnallisia suhteita. Ja tästä johtuu, että Marx ei periaatteessa voi esittää mitään kommunismin hyvän elämän yhteiskunnallisia kriteereitä tai mitään yhteiskunnallista "organisaatioprinsiippiä", vaan joutuu luonnehtimaan sitä "vanhan maailman" käsittein. Niin Lohmannin habermasilainen tulkinta, jota olen itse käsitellyt, kuin Heiskalankin helleriläinen tulkinta ylittävät tämän ongelman, mutta vain sillä ehdolla, että ne samalla joutuvat postuloimaan sekä sellaisia sosiaalisia muodostumia ja suhteita että normatiivisia kriteereitä, joita Marx ei lainkaan kăsittele eikä oman kapitalismikritiikkinsä puitteissa voikaan käsitellä, ja jotka systemaattisesti kehiteltyinä johtaisivat eräiden Marxin keskeisten peruskäsitysten hylkäämiseen. Lohman on tästä tietoinen, Heiskala ei. Ja tämä on myös oman Marxin kommunismikäsitysten ongelmallisuutta koskevan artikkelini perusidea: en ole vain pyrkinyt eksplikoimaan Marxin kommunismikäsitystä, vaan myös problematisoimaan eräitä hänen peruskäsitteitään ja käsityksiään. Samaa on- gelmaa käsittelevät myös eräät muut kokoelmani artikkelit, vaikkakin eittämättä vielä varsin "hämärässä" muodossa.

Jukka Gronow 